\title{
Spawning Habitat Unsuitability: An Impediment to Cisco Rehabilitation in Lake Michigan?
}

\author{
Charles P. Madenjian* \\ U.S. Geological Survey, Great Lakes Science Center, 1451 Green Road, Ann Arbor, \\ Michigan 48105, USA
}

\section{Edward S. Rutherford}

National Oceanic and Atmospheric Administration, Great Lakes Environmental Research Laboratory, 4840 South State Road, Ann Arbor, Michigan 48108, USA

\section{Marc A. Blouin}

U.S. Geological Survey, Coastal and Marine Science Center, 600 Fourth Street South, St. Petersburg, Florida 33701, USA

\author{
Bryan J. Sederberg \\ Enbridge Energy, 1601 Pratt Avenue, Marshall, Michigan 49068, USA
}

\section{Jeff R. Elliott}

School of Natural Resources and Environment, University of Michigan, 440 Church Street, Ann Arbor, Michigan 48109, USA

\begin{abstract}
The cisco Coregonus artedi was one of the most important native prey fishes in Lake Michigan and in the other four Laurentian Great Lakes. Most of the cisco spawning in Lake Michigan was believed to have occurred in Green Bay. The cisco population in Lake Michigan collapsed during the 1950s, and the collapse was attributed in part to habitat degradation within Green Bay. Winter water quality surveys of lower Green Bay during the 1950s and 1960s indicated that the bottom dissolved oxygen (DO) concentration was less than $2 \mathrm{mg} / \mathrm{L}$ throughout much of the lower bay, and most cisco eggs would not successfully hatch at such low DO concentrations. To determine present-day spawning habitat suitability in lower Green Bay, we compared cisco egg survival in lower Green Bay with survival at a reference site (St. Marys River, Michigan-Ontario) during 2009. We also conducted winter water quality surveys in lower Green Bay and the St. Marys River during 2009 and 2010. Cisco egg survival in lower Green Bay averaged $\mathbf{6 5 . 3 \%}$, which was remarkably similar to and not significantly different from the mean at the St. Marys River site $(64.0 \%)$. Moreover, the lowest bottom DO concentrations recorded during the winter surveys were $11.2 \mathrm{mg} / \mathrm{L}$ in lower Green Bay and $12.7 \mathrm{mg} / \mathrm{L}$ in the St. Marys River. These relatively high DO concentrations would not be expected to have any negative effect on cisco egg survival. We conclude that winter water quality conditions in lower Green Bay were suitable for successful hatching of cisco eggs and that water quality during the egg incubation period did not represent an impediment to cisco rehabilitation in Lake Michigan. Our approach to determining spawning habitat suitability for coregonids would be applicable to other aquatic systems.
\end{abstract}

*Corresponding author: cmadenjian@usgs.gov

Received May 14, 2011; accepted July 6, 2011

Published online November 14, 2011 
The cisco Coregonus artedi was once one of the most important native prey fishes in the food webs of all five Laurentian Great Lakes (Dryer et al. 1965; E. H. Brown et al. 1999; R. W. Brown et al. 1999). As abundant offshore planktivores, ciscoes played a key role in transforming biological production from the large offshore pelagic zone into the fish biomass needed to support predator fishes (E. H. Brown et al. 1999). In addition, cisco populations in the Laurentian Great Lakes supported valuable commercial fisheries (R. W. Brown et al. 1999).

Cisco populations in all five Laurentian Great Lakes collapsed between 1920 and 1970 (Berst and Spangler 1973; Christie 1973; Hartman 1973; Lawrie and Rahrer 1973; Wells and McLain 1973). These collapses have been attributed to a number of factors, including overfishing, environmental degradation, and adverse effects of nonnative alewives Alosa pseudoharengus and rainbow smelt Osmerus mordax. The cisco population in Lake Superior recovered during the 1980s, but lakewide recovery of cisco populations has not been attained in the other four lakes (Madenjian et al. 2002; Bronte et al. 2003; Mills et al. 2003; Dobiesz et al. 2005). Commercial harvest data for Lakes Michigan and Huron suggest that ciscoes heavily rely on just a few key spawning areas within a lake to sustain the lake's population. For example, during 1920-1960, 90\% of the commercial cisco harvest in Lake Michigan was from Green Bay and $65 \%$ of the commercial cisco harvest in Lake Huron was from Saginaw Bay (Baldwin et al. 2006).

Madenjian et al. (2008) proposed that the cisco collapses in Lakes Michigan, Huron, Erie, and Ontario were primarily due to environmental degradation of key spawning areas in conjunction with overfishing. Destruction of key spawning habitat preceded the collapse of cisco populations in Lakes Michigan, Huron, and Erie by 10-15 years. Dissolved oxygen (DO) concentrations below $1 \mathrm{mg} / \mathrm{L}$ were observed in lower Green Bay under the ice on the lake bottom in 1938, and the problem worsened by 1955 (Epstein et al. 1974). Further, burrowing mayflies Hexagenia spp. were extirpated from Green Bay during the 1950s, presumably due to low DO concentrations. Ciscoes typically spawn in November, and their eggs incubate under the ice and then hatch in early spring (Cucin and Faber 1985). Dissolved oxygen concentrations of $1 \mathrm{mg} / \mathrm{L}$ could result in greater than 90\% cisco egg mortality (Brooke and Colby 1980). Although DO concentrations under the ice in inner Saginaw Bay have apparently not been measured, the bay received high biochemical oxygen demand loadings during 1930-1970 (Freedman 1974). Extirpation of burrowing mayflies from Saginaw Bay during the 1950s has been attributed to low DO concentrations (Freedman 1974). The collapses of the cisco fisheries in Lake Michigan by 1960 and in Lake Huron by 1956 were probably linked to low DO concentrations under the ice (in lower Green Bay and inner Saginaw Bay, respectively) during the 1940s and 1950s. Because cisco longevity exceeds 20 years (Schreiner and Schram 2001), these cisco collapses appeared to be synchronized with the destruction of spawning habitat 10-15 years earlier. In contrast, large-scale destruction of habitat apparently did not occur in the key spawning areas of Lake Superior-namely Black Bay, Thunder Bay, and the Apostle Islands (Bronte et al. 2003).

Environmental degradation of key spawning areas could still represent a serious impediment to lakewide recovery of cisco populations in Lakes Michigan, Huron, Erie, and Ontario. Although phosphorus, sediment, and biochemical oxygen demand loadings to lower Green Bay from the Fox River decreased from the 1950s to 1990, deliveries of these materials from the Fox River to lower Green Bay still occur at a relatively high rate in comparison with rates from other Lake Michigan tributaries (Epstein et al. 1974; Robertson 1997). Even though early signs of a burrowing mayfly recovery in the lower Fox River have been detected, the burrowing mayfly population in lower Green Bay has yet to recover (Cochran 1992; Cochran and Kinziger 1997; Edsall et al. 2005; J. Kennedy, Green Bay Metropolitan Sewerage District, Green Bay, Wisconsin, personal communication). Moreover, the burrowing mayfly population in inner Saginaw Bay has not yet recovered (Edsall et al. 2005; T. Nalepa, National Oceanic and Atmospheric Administration, Great Lakes Environmental Research Laboratory, Ann Arbor, Michigan, personal communication). Areas of Lake Ontario that are believed to be key cisco spawning areas, including Hamilton Harbour and Irondequoit Bay, remain highly degraded (Fitzsimons and O'Gorman 2006).

Rehabilitation of cisco populations in Lakes Michigan, Huron, Erie, and Ontario is a highly desirable goal of fishery managers (Stockwell et al. 2009; Zimmerman and Krueger 2009). Recovery of the cisco population could facilitate the rehabilitation of lake trout Salvelinus namaycush, the top native coldwater predator in these four lakes (Fitzsimons and O'Gorman 2006). In addition, increasing the proportion of ciscoes in the planktivore community could better stabilize the food webs in these lakes.

The overall goal of our study was to determine whether the present-day spawning habitat quality in lower Green Bay is adequate for successful incubation of cisco eggs. To accomplish this goal, we treated the St. Marys River (Michigan-Ontario) as our reference area and lower Green Bay as our target area. During the past 40 years, ciscoes have remained relatively abundant in the St. Marys River, which connects Lakes Superior and Huron (Savino et al. 1994; Fielder 1998). In contrast, ciscoes have been nearly absent from lower Green Bay during the past 40 years (Madenjian et al. 2002). Our specific objectives were to (1) determine whether cisco egg survival varied significantly between the St. Marys River and lower Green Bay; and (2) determine, via winter water quality surveys, whether DO concentrations in the two areas were sufficiently high to allow for high cisco egg survival.

\section{METHODS}

Study sites.-Our reference site was located near the western shore of Sugar Island in the St. Marys River (Figure 1). Bottom depth at the reference site was $5.1 \mathrm{~m}$. Our target area was lower 


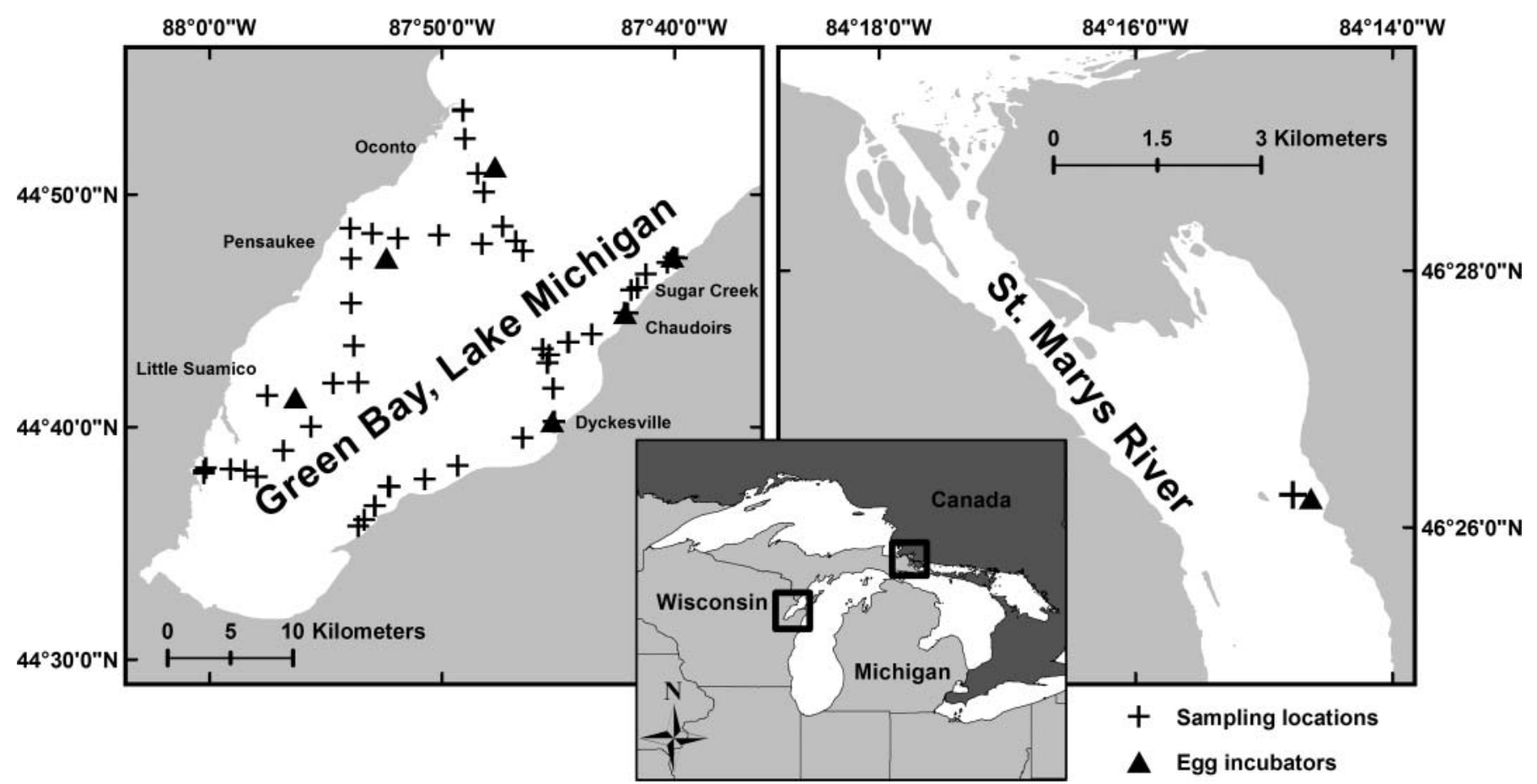

FIGURE 1. Study sites in lower Green Bay (Wisconsin) and the St. Marys River (Michigan-Ontario), where cisco egg survival experiments and water quality surveys were conducted during winter 2009 and 2010.

Green Bay (Figure 1). For cisco egg incubations, we selected three sites on the western side and three sites on the eastern side of lower Green Bay. The sites on the western side were near the Wisconsin towns of Oconto (bottom depth at this site $=6.2 \mathrm{~m}$ ), Pensaukee (bottom depth $=5.4 \mathrm{~m}$ ), and Little Suamico (bottom depth $=6.3 \mathrm{~m}$ ). The sites on the eastern side were located near (1) the Sugar Creek launch ramp (bottom depth $=8.0 \mathrm{~m}$ ), (2) the Chaudoirs launch ramp (bottom depth $=4.8 \mathrm{~m}$ ), and (3) the town of Dyckesville, Wisconsin (bottom depth $=5.5 \mathrm{~m}$ ).

Cisco egg incubations. - We obtained cisco eggs from the Wolf Lake State Fish Hatchery (Michigan Department of Natural Resources [MDNR], Mattawan). These eggs originated from 20 adult females in spawning condition that were caught near the western shore of Sugar Island in the St. Marys River during midNovember 2008. The eggs reached the eyed stage during late December 2008. At the Wolf Lake State Fish Hatchery, cisco eggs were introduced into Plexiglas incubator chambers (Manny et al. 1989) on 15 and 21 January 2009 for subsequent placement into the St. Marys River and lower Green Bay, respectively. The egg incubation site in the St. Marys River was chosen to be in close proximity to the original area of capture for the adult broodstock. We placed one fertilized cisco egg into each well (diameter $=$ $1 \mathrm{~cm}$ ) of the 50-well incubators, and we covered each incubator with $500-\mu \mathrm{m}$-mesh Nitex screening to prevent egg predation. Eggs were also held at the Wolf Lake State Fish Hatchery to determine egg survival under laboratory conditions. Incubators were transported from the hatchery to the study sites in coolers filled with ice water (water temperature was kept below $3^{\circ} \mathrm{C}$ ).
On 16 January 2009, three replicate incubation chambers were deployed at the St. Marys River site. On 21 January 2009, fertilized cisco eggs were loaded into incubators and transported to lower Green Bay; the incubation chambers were then deployed at the six sites (3 replicates/site) over the next two days (22-23 January 2009). At each site, three replicate incubation chambers were attached ( $\sim 30 \mathrm{~cm}$ apart) along a chain linked to an anchor. A hole was drilled through the ice, and the set of incubators, chain, anchor, and a marker buoy were guided through the hole and lowered to the bottom. The position of each of the seven incubator sites was marked with a Global Positioning System unit. After ice-out, the egg incubators were retrieved by scuba divers at the St. Marys River site on 23 April 2009 and at the lower Green Bay sites on 28-29 April 2009. Egg survival was recorded on the same day as retrieval from the water. Egg survival was defined as the percentage of the 50 incubator wells that contained live eggs, live larvae, or dead larvae. Egg survival under the controlled temperature $\left(3.3^{\circ} \mathrm{C}\right)$ and flow conditions at the Wolf Lake State Fish Hatchery was measured by MDNR personnel.

To determine the approximate hatch date, we aged a subset of the cisco larvae recovered from the incubators in lower Green Bay by using the technique described by Oyadomari and Auer (2007). Otoliths were removed from the larvae, and daily rings on the otoliths were counted. Total length of each larva was also measured.

Winter water quality surveys. - We conducted winter water quality surveys of lower Green Bay on 20 and 21 February 2009, 14 and 15 March 2009, 2 February 2010, and 24 February 2010. 
Between 25 and 40 different sites in the lower bay were sampled during each survey. To sample a variety of bottom depths, we selected sites in a zigzag pattern along the western and eastern sides of the lower bay (Figure 1). At each site, a hole was drilled through the ice and a YSI Model 6600 sonde (YSI, Inc., Yellow Springs, Ohio) was then slowly lowered by rope to the bottom, pausing for at least $10 \mathrm{~s}$ at $1-\mathrm{m}$ depth intervals, and was kept at bottom for at least $30 \mathrm{~s}$ before being retrieved. The sonde was programmed to record DO concentration $(\mathrm{mg} / \mathrm{L})$, water temperature $\left({ }^{\circ} \mathrm{C}\right)$, specific conductivity $(\mu \mathrm{S} / \mathrm{cm}), \mathrm{pH}$, and water depth (m) every 4 s. A Global Positioning System unit was used to mark the location of each sampling site. Due to a data recording problem with the sonde on 14 and 15 March 2009, water quality data from that particular survey were available only for the eastern side and two sites on the western side of lower Green Bay. In addition to the aforementioned survey work, we used the YSI Model 6600 sonde to measure water quality conditions at each of the six egg incubation sites in lower Green Bay on 22 and 23 January 2009 (i.e., the dates of incubator deployment). We also sampled the same six incubation sites during each of the winter water quality surveys in lower Green Bay.

Winter water quality surveys in the St. Marys River were conducted on 29 January, 12 February, 12 March, and 26 March in 2009 and 28 January, 12 February, and 22 February in 2010. During all surveys, we sampled one St. Marys River site $\left(46^{\circ} 26^{\prime} 11.76^{\prime \prime} \mathrm{N}, 84^{\circ} 14^{\prime} 38.76^{\prime \prime} \mathrm{W}\right)$ that was in close proximity to the cisco egg incubation site used during 2009 (Figure 1). The sampling procedure used at the St. Marys River site was similar to that used in lower Green Bay. In 2009, a Hydrolab Quanta Monitoring System (Hydrolab Corporation, Austin, Texas) was used to measure DO concentration, water temperature, specific conductivity, pH, and water depth. In 2010, a YSI Model 85 meter was used to measure DO concentration and water temperature $\left({ }^{\circ} \mathrm{C}\right)$. In both years, the measuring instrument was slowly lowered, pausing for at least $10 \mathrm{~s}$ at depth and for at least $30 \mathrm{~s}$ on the bottom, and values were recorded from just below the ice to the bottom at 1-m depth intervals. In addition to the above-mentioned survey work, we also measured water quality conditions in the St. Marys River at the egg incubation site on the incubator deployment date (16 January 2009).

Data analyses.-To determine whether cisco egg survival differed significantly among the seven sites, we performed a one-way analysis of variance (ANOVA) with egg survival as the dependent variable and site as the main effect. There were three replicate estimates of egg survival for each site. Thus, our ANOVA design was balanced. After performing the ANOVA, we used Dunnett's multiple comparison procedure (Miller 1981) to compare the mean egg survival at each of the six Green Bay sites with mean egg survival at the St. Marys River site. The one-way ANOVA was also followed by a contrast (Neter and Wasserman 1974); to perform this contrast, egg survival was averaged across all six sites in lower Green Bay to compute a grand mean, which was then compared with the mean egg survival for the St. Marys River site. The least detectable true change for the contrast was calculated to assess the power of the contrast in detecting a significant difference in mean egg survival between lower Green Bay and the St. Marys River (Sokal and Rohlf 1969; Jude et al. 1975). The significance level $\alpha$ was set at 0.05 for all statistical tests.

The bottom DO concentrations and the corresponding latitude-longitude coordinates recorded during the 2009-2010 winter water quality surveys of lower Green Bay were entered into a geographical information system (GIS). We then used the GIS to prepare DO concentration maps of lower Green Bay for each of the four winter surveys. Bottom DO concentrations reported by Epstein et al. (1974) for winter water quality surveys performed in lower Green Bay during February and March of 1966-1967 were also entered into the GIS to generate winter DO maps based on these historical data.

To summarize data from our winter water quality surveys, we calculated the mean and SE of DO concentration, water temperature, specific conductivity, and $\mathrm{pH}$ measured on bottom for lower Green Bay and the St. Marys River site in each year. In addition, the minimum bottom DO concentration observed during all winter sampling (2009-2010) was determined for lower Green Bay and the St. Marys River.

\section{RESULTS}

\section{Cisco Egg Incubations}

Cisco egg survival in lower Green Bay averaged $65.3 \%$ at the Oconto site, $72.0 \%$ at Pensaukee, $70.7 \%$ at Little Suamico, 75.3\% at Sugar Creek, $52.7 \%$ at Chaudoirs, and $56.0 \%$ at Dyckesville; egg survival averaged $64.0 \%$ at the St. Marys River site (Figure 2). Egg survival did not significantly differ among the seven sites (one-way ANOVA: $F=1.02$; $\mathrm{df}=6,14$; $P=0.4523$ ). Furthermore, egg survival did not significantly differ between each of the six Green Bay sites and the St. Marys River site (Dunnett's multiple comparison test: all $P>0.05$ ). The grand mean survival for the lower Green Bay sites was

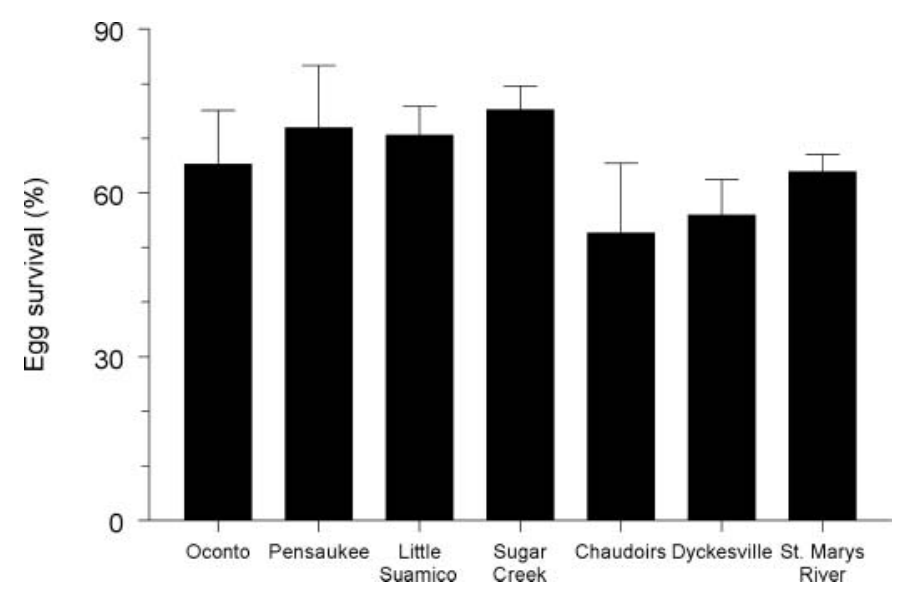

FIGURE 2. Mean ( \pm SE) survival of cisco eggs in incubation chambers at six sites in lower Green Bay and at one site in the St. Marys River, January-April 2009. 


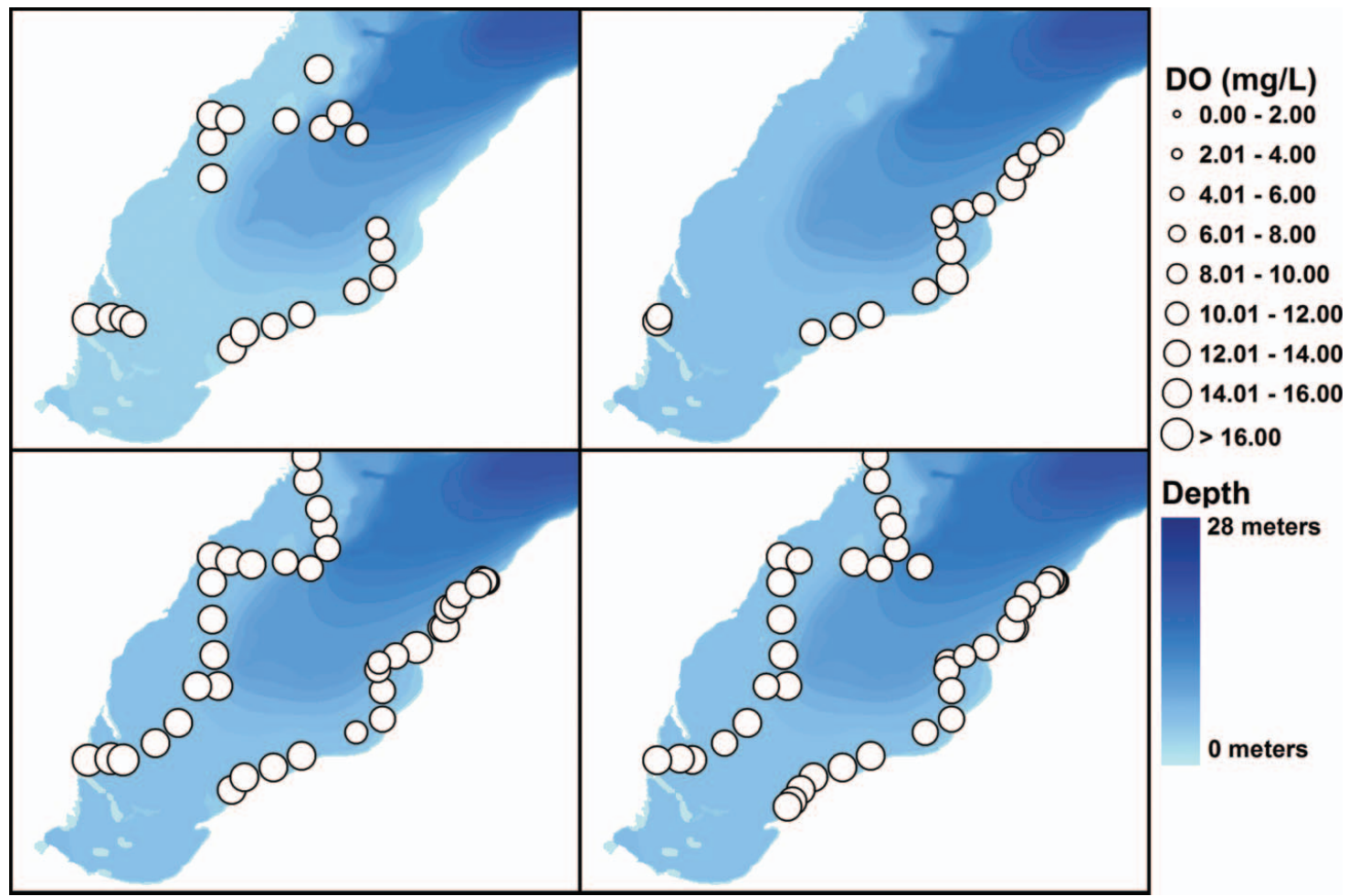

FIGURE 3. Dissolved oxygen (DO) concentrations observed on bottom in lower Green Bay during 20-21 February 2009 (upper left panel), 14-15 March 2009 (upper right panel), 2 February 2010 (lower left panel), and 24 February 2010 (lower right panel).

$65.3 \%$ and did not significantly differ from the mean for the St. Marys River site (contrast: $t=0.15 ; \mathrm{df}=14 ; P=0.8840$ ). Calculation of the least detectable true change revealed that mean cisco egg survival would have had to differ by at least $19.2 \%$ between the target and reference sites for a significant difference to be detected. At the hatchery, cisco egg survival from the eye-up stage to hatch was $80 \%$ (M. Hughes, Wolf Lake State Fish Hatchery, personal communication).

Average age of the nine cisco larvae that were examined from the egg incubators was $37 \mathrm{~d}$, and age ranged from 32 to 42 d. Given that we retrieved the incubators on 28-29 April 2009 , the average hatch date of these larvae was estimated as 23 March 2009. Total length of the cisco larvae averaged $11.4 \mathrm{~mm}$ and ranged from 9.3 to $17.3 \mathrm{~mm}$.

\section{Winter Water Quality Surveys}

When cisco egg incubators were first introduced into the St. Marys River (16 January 2009), the bottom DO concentration at the incubator site was $14.1 \mathrm{mg} / \mathrm{L}$. When the incubators were first deployed in lower Green Bay (22-23 January 2009), the bottom DO concentrations at the six sites ranged from 12.9 to $14.5 \mathrm{mg} / \mathrm{L}$.

For lower Green Bay, water quality results from the 20-21 February 2009 survey showed that bottom DO concentration ranged from 11.7 to $18.8 \mathrm{mg} / \mathrm{L}$ (Figure 3). During the $14-15$ March 2009 survey, bottom DO concentrations in the lower bay ranged from 11.2 to $22.3 \mathrm{mg} / \mathrm{L}$. Results from the 2010 surveys were similar to the results from 2009. Bottom DO concentrations in lower Green Bay ranged from 11.4 to $17.7 \mathrm{mg} / \mathrm{L}$ on 2 February 2010 and from 12.3 to $15.6 \mathrm{mg} / \mathrm{L}$ on 24 February 2010 (Figure 3). Bottom depth at the sampling sites in lower Green Bay ranged from 0.2 to $13.6 \mathrm{~m}$.

Bottom DO concentrations observed at the St. Marys River site were within the ranges observed for lower Green Bay. During the 2009 surveys, the bottom DO concentrations at the St. Marys River site were $13.6 \mathrm{mg} / \mathrm{L}$ on 29 January, $14.4 \mathrm{mg} / \mathrm{L}$ on 12 February, $13.6 \mathrm{mg} / \mathrm{L}$ on 26 February, $12.7 \mathrm{mg} / \mathrm{L}$ on 12 March, and $14.5 \mathrm{mg} / \mathrm{L}$ on 26 March. During the 2010 surveys, the bottom DO concentrations were $15.3 \mathrm{mg} / \mathrm{L}$ on 28 January, $16.0 \mathrm{mg} / \mathrm{L}$ on 12 February, and $15.7 \mathrm{mg} / \mathrm{L}$ on 25 February.

Overall, the overwinter bottom DO concentrations were similar between the St. Marys River site and lower Green Bay. Mean bottom DO concentrations during winter 2009 were nearly identical between the two areas, averaging $13.9 \mathrm{mg} / \mathrm{L}$ for lower Green Bay and $13.8 \mathrm{mg} / \mathrm{L}$ for the St. Marys River site (Table 1). During winter 2010, mean bottom DO concentration at the St. Marys River site $(15.7 \mathrm{mg} / \mathrm{L})$ was slightly higher than that in lower Green Bay (14.2 mg/L). The lowest bottom DO concentrations observed during the winter water quality surveys were $11.2 \mathrm{mg} / \mathrm{L}$ for lower Green Bay and $12.7 \mathrm{mg} / \mathrm{L}$ for the St. Marys River site. 
TABLE 1. Mean (SE in parentheses) water temperature, specific conductivity, $\mathrm{pH}$, and dissolved oxygen (DO) concentration observed on bottom in lower Green Bay (GB; mean depth of sites sampled $=5.3 \mathrm{~m}$ ) and the St. Marys River (SMR; mean depth $=5.1 \mathrm{~m}$ ) during January-March in 2009 and $2010(\mathrm{ND}=$ no data available).

\begin{tabular}{lcccc}
\hline Area and year & Temperature $\left({ }^{\circ} \mathrm{C}\right)$ & Specific conductivity $(\mu \mathrm{S} / \mathrm{cm})$ & $\mathrm{pH}$ & DO concentration $(\mathrm{mg} / \mathrm{L})$ \\
\hline GB 2009 $(N=56)$ & $0.98(0.04)$ & $370(5)$ & $7.81(0.04)$ & $13.85(0.14)$ \\
SMR 2009 $(N=6)$ & $0.01(0.06)$ & $103(23)$ & $7.25(0.06)$ & $13.79(0.14)$ \\
GB 2010 $(N=79)$ & $1.89(0.05)$ & $354(4)$ & $7.98(0.02)$ & $14.21(0.07)$ \\
SMR 2010 $(N=3)$ & $0.20(0.03)$ & ND & ND & $15.68(0.10)$ \\
\hline
\end{tabular}

Overwinter bottom water temperature tended to be higher in lower Green Bay than at the St. Marys River site (Table 1). Similarly, specific conductivity on bottom during the winter was greater in lower Green Bay than at the St. Marys River site. Bottom $\mathrm{pH}$ in lower Green Bay was slightly higher than bottom $\mathrm{pH}$ at the St. Marys River site during winter (Table 1).

Based on data reported by Epstein et al. (1974), mapping of the bottom DO concentrations in lower Green Bay for winter 1966 and 1967 revealed that at times, a zone of low DO concentration $(<2 \mathrm{mg} / \mathrm{L})$ extended from the southern end of the bay to locations more than $50 \mathrm{~km}$ from the southernmost reach of the bay (Figure 4). During March 1966, low DO concentrations on bottom were recorded at sites on the eastern side of the bay (Figure 4). During 1967, low bottom DO concentrations were already evident in lower Green Bay by early February and persisted through March (Figure 4). In addition, although Epstein et al. (1974) did not report specific values, they did mention that low bottom DO concentrations were observed during March 1955 on both sides of the southern portion of lower Green Bay. Moreover, Epstein et al. (1974) stated that low bottom DO conditions during winter were also observed in lower Green Bay during 1938. Thus, it is likely that in lower Green Bay, low bottom DO conditions during winter had occurred over a period of at least three decades. Clearly, these historical data indicated that the zone of low bottom DO concentration in Green Bay could extend a substantial distance away from the Fox River mouth, which is located near the southernmost reach of the bay.

\section{DISCUSSION}

From a water quality perspective, present-day spawning habitat conditions in lower Green Bay would not represent an impediment to cisco rehabilitation in Lake Michigan. Cisco egg survival in lower Green Bay was not significantly different from that observed in the St. Marys River, where a stable population of ciscoes has existed for the past 40 years. Moreover, overwinter bottom DO concentrations in lower Green Bay were more than adequate to allow for relatively high survival of cisco eggs. The lowest bottom DO concentration we observed during winter water quality surveys of lower Green Bay was $11.2 \mathrm{mg} / \mathrm{L}$. Results from laboratory experiments by Brooke and Colby (1980) indicated that low DO concentrations $(\leq 2 \mathrm{mg} / \mathrm{L})$ had an adverse effect on cisco egg survival and on the ability of cisco larvae to hatch without deformities and successfully escape from the egg. Overwinter bottom DO concentrations in lower Green Bay during 2009-2010 were well above this critical value of $2 \mathrm{mg} / \mathrm{L}$; therefore, DO concentration would not have had any negative effect on cisco egg survival in lower Green Bay during the two winters we examined.

Clearly, overwinter water quality in lower Green Bay dramatically improved between the 1938-1967 and 2009-2010 time periods. Overwinter bottom DO concentrations of less than $2 \mathrm{mg} / \mathrm{L}$ were frequently observed in lower Green Bay during the 1950s and 1960s (Epstein et al. 1974). Moreover, bottom DO concentrations of $0 \mathrm{mg} / \mathrm{L}$ were recorded at several locations in the lower bay during the same period. In contrast, the lowest bottom DO concentration observed in lower Green Bay during the winters of 2009 and 2010 was $11.2 \mathrm{mg} / \mathrm{L}$. Epstein et al. (1974) primarily attributed the low overwinter bottom DO conditions in lower Green Bay during 1938-1967 to effluent from the pulp and paper industries located along the Fox River, the main tributary to Green Bay. The biochemical oxygen demand of this effluent was unusually high (Epstein et al. 1974; Harris et al. 1982). During the early 1970s, new processing plants were built to treat the effluent (Harris et al. 1982). Therefore, we believe that the operation of these treatment plants beginning in the early 1970s led to the huge improvement in overwinter water quality of lower Green Bay between 1967 and 2009.

Although low winter DO conditions in lower Green Bay apparently no longer occur, low-DO conditions during July and August are still observed: bottom DO concentrations less than $2 \mathrm{mg} / \mathrm{L}$ were measured on 6 August 2007 in the lower portion of the bay (B. DeStasio, Lawrence University, Appleton, Wisconsin, personal communication). Similarly, low bottom DO concentrations in lower Green Bay have been observed by other researchers during summer months over the past 5 years as well (J. Kennedy, Green Bay Metropolitan Sewerage District, personal communication; V. Klump, University of Wisconsin-Milwaukee, personal communication). Apparently, eutrophication still leads to low-DO conditions in lower Green Bay during summer, although the eutrophication problem was substantially more severe during the 1960 s than it is today. It is possible that the persistence of low-DO conditions during summer has continued to prevent the recovery of burrowing mayflies in lower Green Bay. Juvenile ciscoes should be able to actively avoid zones of low DO; therefore, low-DO conditions 


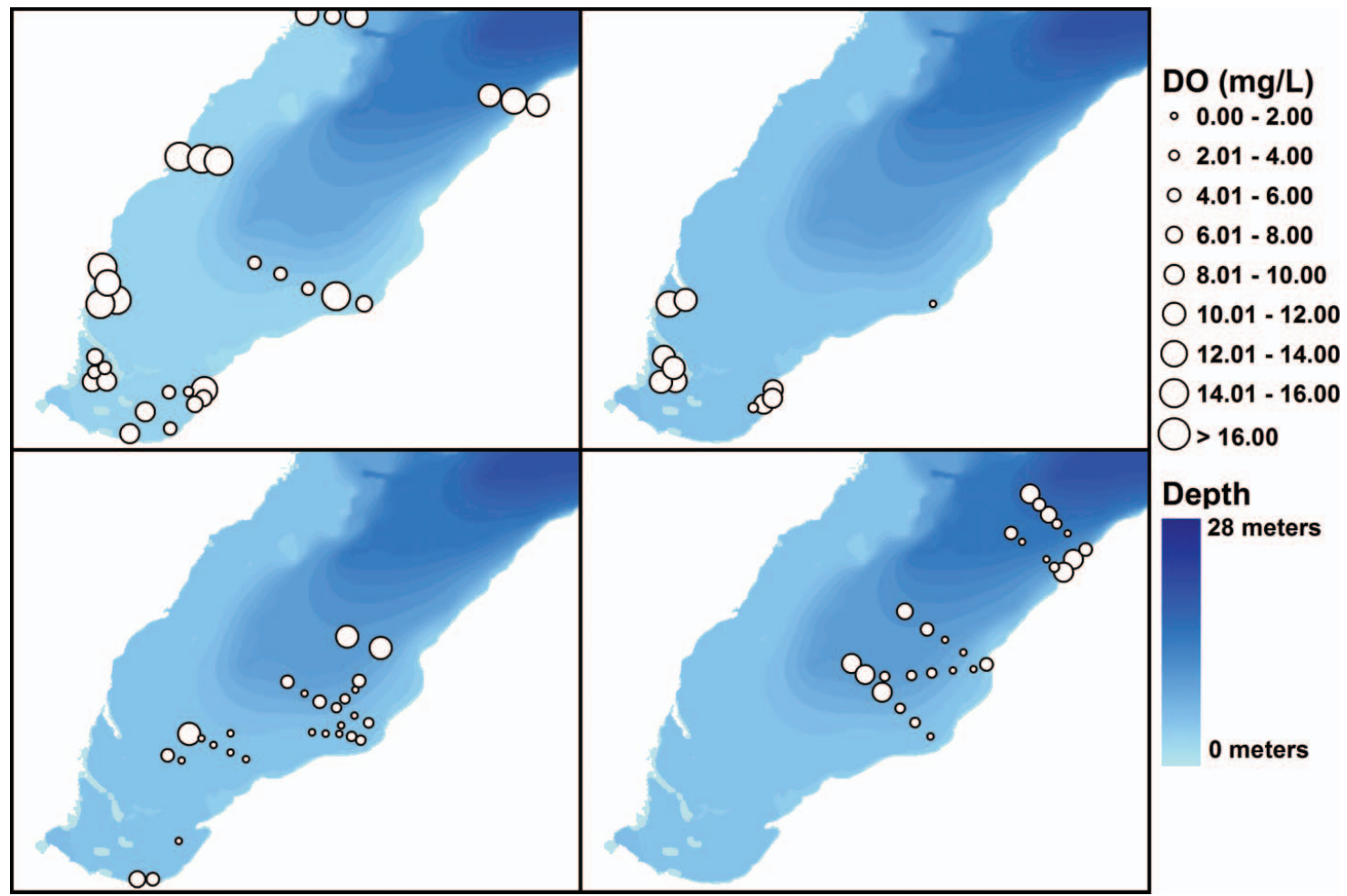

FIGURE 4. Dissolved oxygen (DO) concentrations observed on bottom in lower Green Bay during 9-10 February 1966 (upper left panel), 10 March 1966 (upper right panel), 8-10 February 1967 (lower left panel), and 9-10 March 1967 (lower right panel). Data are from Epstein et al. (1974).

in Green Bay during summer months would not be expected to affect the survival of juvenile ciscoes.

Our average estimate $(64.0 \%)$ of cisco egg survival at the St. Marys River site during winter 2009 was in close agreement with the overall average survival $(66.3 \%)$ estimated by Savino et al. (1994), who incubated cisco eggs at three different sites in the St. Marys River during winter 1992. In addition, Savino et al. (1994) used Plexiglas incubator chambers that were very similar in design to the ones used in the present study.

Our observations of overwinter bottom DO in lower Green Bay ranged as high as $22.3 \mathrm{mg} / \mathrm{L}$, or about $8 \mathrm{mg} / \mathrm{L}$ higher than the $100 \%$ DO saturation value for the water temperature associated with this DO observation. Supersaturation of oxygen in the bay during the winter was plausible given that substantial photosynthetic activity can occur beneath the ice (Greenbank 1945). Furthermore, ice cover prevented wind reaeration, the lack of which can promote oxygen supersaturation of the water (Madenjian et al. 1987).

Factors other than water quality could also affect survival of cisco eggs and larvae. For example, predation has the potential to exert a strong influence on the survival of these life stages. Smith (1970) and Wells and McLain (1973) hypothesized that alewives interfered with cisco reproduction-primarily by predation on cisco larvae-in Lake Michigan during the late 1950s, thereby contributing to the collapse of the cisco population by
1960. However, Madenjian et al. (2008) argued that because ciscoes are long-lived fish, the establishment of the alewife population in Green Bay during 1955 or 1956 was not a feasible explanation for the collapse of the Lake Michigan cisco population by 1960 . Evidence that rainbow smelt predation on cisco larvae has had a significant adverse effect on cisco recruitment in the Laurentian Great Lakes has been inconclusive (Bronte et al. 2003). Nonetheless, predation on cisco eggs, larvae, and fingerlings could still represent an impediment to the rehabilitation of cisco populations in the Laurentian Great Lakes; potential predators include the round goby Neogobius melanostomus and walleye Sander vitreus (Fitzsimons and O'Gorman 2006).

Fishery managers in the Great Lakes region are presently considering whether to stock ciscoes in Lakes Michigan, Huron, Erie, and Ontario to rehabilitate the cisco populations in these lakes (Fitzsimons and O'Gorman 2006; Stockwell et al. 2009; Zimmerman and Krueger 2009). Moreover, rehabilitation of these cisco populations has been viewed as essential for self-sustainability of the lake trout populations and for additional stability of the offshore pelagic food webs. For example, Bowlby et al. (2007) proposed that rehabilitation of the cisco population in Lake Ontario was critical for self-sustainability of salmonines, including lake trout and Atlantic salmon Salmo salar. If habitat quality of the key spawning areas in these lakes is still inadequate for successful cisco reproduction, then attempts 
to rehabilitate the cisco populations via stocking would not be effective. Our study results indicate that water quality in lower Green Bay is sufficient to allow for successful reproduction by ciscoes and that habit quality in lower Green Bay would not impede efforts to restore the cisco population to Lake Michigan. Is the present-day habitat in key spawning areas of Lakes Huron, Erie, and Ontario of suitable quality for successful reproduction by ciscoes? Additional research, including field experimentation, would be needed to answer this question. For example, to the best of our knowledge, no observations of DO concentration under the ice have ever been made in inner Saginaw Bay during winter (Freedman 1974; J. Bredin, MDNR, Lansing, personal communication). Thus, the winter water quality of inner Saginaw Bay, particularly at the bottom, remains to be explored.

We recommend that our approach of using egg incubation accompanied by winter water quality surveys be applied to determine spawning habitat quality in aquatic ecosystems where populations of ciscoes or related species have collapsed due at least in part to environmental degradation of key spawning areas. Our approach need not be limited to cisco populations in the Laurentian Great Lakes. For example, several populations of whitefish Coregonus spp. in European alpine lakes have experienced reproductive failure due to eutrophication and its negative effect on egg survival (Wahl and Löffler 2009). Eutrophication in these lakes has led to low DO concentrations in the spawning areas. For Lake Constance (Germany, Switzerland, and Austria), a regression relationship has been developed for the percentage of viable eggs of the blaufelchen C. lavaretus wartmanii (a native whitefish) as a function of DO concentration on the lake bottom within the spawning area (Wahl and Löffler 2009). The blaufelchen eggs in Lake Constance have been sampled by dredges each winter since 1968. Our approach of overwinter egg incubation yields an in situ estimate of egg survival. Furthermore, incubation of eggs at both a target area and a reference area allows for a comparison of egg survival between the two areas. In addition, by use of winter water quality surveys, bottom DO concentrations can be compared between the target and reference areas. Finally, comparison of the overwinter DO concentrations at the target and reference sites with critical DO concentrations established from laboratory experiments would further enable researchers to make conclusions about the suitability of water quality at the target sites for successful natural reproduction by coregonids.

\section{ACKNOWLEDGMENTS}

We thank the Chippewa Ottawa Resource Authority biologists and MDNR biologists who captured adult ciscoes from the St. Marys River. We are also grateful to Martha Wolgamood (Wolf Lake State Fish Hatchery) for advice and assistance; Matt Hughes and Scott Zajac (Wolf Lake State Fish Hatchery) for hatchery assistance; Peter Boma for piloting the airboat and assisting in the field; Jeff Allen and Glen Black for scuba diving efforts during egg retrieval; Jon Molenhouse, Brandon Spude,
Michael Fainter, and David Sena for dedicated efforts in the winter water quality survey work; Geoffrey Steinhart and his graduate students at Lake Superior State University for winter water quality survey work at the St. Marys River site; and Christine Joseph, Minako Kimura Edgar, and Lacey Mason for GIS assistance. We appreciate the storage space and logistical support provided by the U.S. Fish and Wildlife Service Green Bay Fishery Resources Office (New Franken, Wisconsin). Harold Mohr kindly provided winter access to the St. Marys River site. Doran Mason and Craig Stow reviewed the draft manuscript and made helpful suggestions for its improvement. Use of trade, product, or firm names does not imply endorsement by the U.S. Government. This research was funded by a Great Lakes Fish and Wildlife Restoration Act grant (U.S. Fish and Wildlife Service) to E.S.R and C.P.M. This article is Contribution Number 1656 of the U.S. Geological Survey, Great Lakes Science Center and is Contribution Number 1595 of the Great Lakes Environmental Research Laboratory.

\section{REFERENCES}

Baldwin, N. A., R. W. Saalfeld, M. R. Dochoda, H. J. Buettner, and R. L. Eshenroder. 2006. Commercial fish production in the Great Lakes, 1867-2006. Great Lakes Fishery Commission, Ann Arbor, Michigan. Available: www.glfc.org/databases/commercial/commerc.php. (May 2011).

Berst, A. H., and G. R. Spangler. 1973. Lake Huron: the ecology of the fish community and man's effects on it. Great Lakes Fishery Commission Technical Report 21.

Bowlby, J. N., J. A. Hoyle, T. Schaner, D. L. Bishop, M. E. Daniels, T. H. Eckert, B. F. Lantry, R. O'Gorman, and R. W. Owens. 2007. The offshore pelagic fish community. Pages 75-88 in B. J. Morrison and S. R. LaPan, editors. The state of Lake Ontario in 2003. Great Lakes Fishery Commission, Special Publication 07-01, Ann Arbor, Michigan.

Bronte, C. R., M. P. Ebener, D. R. Schreiner, D. S. DeVault, M. M. Petzold, D. A. Jensen, C. Richards, and S. J. Lozano. 2003. Fish community change in Lake Superior, 1970-2000. Canadian Journal of Fisheries and Aquatic Sciences 60:1552-1574.

Brooke, L. T., and P. J. Colby. 1980. Development and survival of embryos of lake herring at different constant oxygen concentrations and temperatures. Progressive Fish-Culturist 42:3-9.

Brown, E. H. Jr., T. R. Busiahn, M. L. Jones, and R. L. Argyle. 1999. Allocating Great Lakes forage bases in response to multiple demands. Pages 355-396 in W. W. Taylor and C. P. Ferreri, editors. Great Lakes fisheries policy and management: a binational perspective. Michigan State University Press, East Lansing.

Brown, R. W., M. Ebener, and T. Gorenflo. 1999. Great Lakes commercial fisheries: historical overview and prognosis for the future. Pages 307-354 in W. W. Taylor and C. P. Ferreri, editors. Great Lakes fisheries policy and management: a binational perspective. Michigan State University Press, East Lansing.

Christie, W. J. 1973. A review of the changes in the fish species composition of Lake Ontario. Great Lakes Fishery Commission Technical Report 23.

Cochran, P. A. 1992. The return of Hexagenia (Ephemeroptera: Ephemeridae) to the lower Fox River, Wisconsin. Great Lakes Entomologist 25:79-81.

Cochran, P. A., and A. P. Kinziger. 1997. Hexagenia bilineata (Ephemeroptera: Ephemeridae) persists at low levels of abundance in the lower Fox River, Wisconsin. Great Lakes Entomologist 30:89-92.

Cucin, D., and D. J. Faber. 1985. Early life history studies of lake whitefish (Coregonus clupeaformis), cisco (Coregonus artedii) and yellow perch (Perca flavescens) in Lake Opeongo, Ontario. Ontario Ministry of Natural Resources, Ontario Fisheries Technical Report Series 16, Toronto. 
Dobiesz, N. E., D. A. McLeish, R. L. Eshenroder, J. R. Bence, L. C. Mohr, M. P. Ebener, T. F. Nalepa, A. P. Woldt, J. E. Johnson, R. L. Argyle, and J. C. Makarewicz. 2005. Ecology of the Lake Huron fish community, 1970-1999. Canadian Journal of Fisheries and Aquatic Sciences 62:1432-1451.

Dryer, W. R., L. F. Erkkila, and C. L. Tetzloff. 1965. Food of lake trout in Lake Superior. Transactions of the American Fisheries Society 94:169-176.

Edsall, T. A., M. T. Bur, O. T. Gorman, and J. S. Schaeffer. 2005. Burrowing mayflies as indicators of ecosystem health: status of populations in western Lake Erie, Saginaw Bay and Green Bay. Aquatic Ecosystem Health and Management 8:107-116.

Epstein, E., M. Bryans, D. Mezei, and D. Patterson. 1974. Lower Green Bay: an evaluation of existing and historical conditions. U.S. Environmental Protection Agency, Report EPA-905/9-74-006, Chicago.

Fielder, D. G. 1998. Lake herring spawning grounds of the St. Marys River with potential effects of early spring navigation. Michigan Department of Natural Resources, Fisheries Research Report 2049, Ann Arbor.

Fitzsimons, J. D., and R. O'Gorman. 2006. Status and assessment, research, and restoration needs for lake herring in the Great Lakes. Canadian Technical Report of Fisheries and Aquatic Sciences 2638.

Freedman, P. L. 1974. Saginaw Bay: an evaluation of existing and historical conditions. U.S. Environmental Protection Agency, Report 905/9-74-003, Chicago.

Greenbank, J. 1945. Limnological conditions in ice-covered lakes, especially as related to winter-kill of fish. Ecological Monographs 15:343-392.

Harris, H. J., D. R. Talheim, J. J. Magnuson, and A. M. Forbes. 1982. Green Bay in the future - a rehabilitative prospectus. Great Lakes Fishery Commission Technical Report 38.

Hartman, W. L. 1973. Effects of exploitation, environmental changes, and new species on the fish habitats and resources of Lake Erie. Great Lakes Fishery Commission Report 22.

Jude, D. J., F. J. Tesar, J. A. Dorr III, T. J. Miller, P. J. Rago, and D. J. Stewart. 1975. Inshore Lake Michigan fish populations near the Donald C. Cook Nuclear Power Plant, 1973. Great Lakes Research Division, University of Michigan, Special Report 52, Ann Arbor.

Lawrie, A. H., and J. F. Rahrer. 1973. Lake Superior: a case history of the lake and its fisheries. Great Lakes Fishery Commission Technical Report 19.

Madenjian, C. P., G. L. Fahnenstiel, T. H. Johengen, T. F. Nalepa, H. A. Vanderploeg, G. W. Fleischer, P. J. Schneeberger, D. M. Benjamin, E. B. Smith, J. R. Bence, E. S. Rutherford, D. S. Lavis, D. M. Robertson, D. J. Jude, and M. P. Ebener. 2002. Dynamics of the Lake Michigan food web, 1970-2000. Canadian Journal of Fisheries and Aquatic Sciences 59:736-753.

Madenjian, C. P., R. O'Gorman, D. B. Bunnell, R. L. Argyle, E. F. Roseman, D. M. Warner, J. D. Stockwell, and M. A. Stapanian. 2008. Adverse effects of alewives on Laurentian Great Lakes fish communities. North American Journal of Fisheries Management 28:263-282.
Madenjian, C. P., G. L. Rogers, and A. W. Fast. 1987. Predicting night time dissolved oxygen loss in prawn ponds of Hawaii: part II. A new method. Aquacultural Engineering 6:209-225.

Manny, B. A., D. J. Jude, and R. L. Eshenroder. 1989. Field test of a bioassay procedure for assessing habitat quality on fish spawning grounds. Transactions of the American Fisheries Society 118:175-182.

Miller, R. G. Jr. 1981. Simultaneous statistical inference, 2nd edition. SpringerVerlag, New York.

Mills, E. L., J. M. Casselman, R. Dermott, J. D. Fitzimons, G. Gal, K. T. Holeck, J. A. Hoyle, O. E. Johannsson, B. F. Lantry, J. C. Makarewicz, E. S. Millard, I. F. Munawar, M. Munawar, R. O'Gorman, R. W. Owens, L. G. Rudstam, T. Shaner, and T. J. Stewart. 2003. Lake Ontario: food web dynamics in a changing ecosystem (1970-2000). Canadian Journal of Fisheries and Aquatic Sciences 60:471-490.

Neter, J., and W. Wasserman. 1974. Applied linear statistical models. Irwin, Homewood, Illinois.

Oyadomari, J. K., and N. A. Auer. 2007. Influence of rearing temperature and feeding regime on otolith increment deposition in larval ciscoes. Transactions of the American Fisheries Society 136:766-777.

Robertson, D. M. 1997. Regionalized loads of sediment and phosphorus to lakes Michigan and Superior-high flow and long-term average. Journal of Great Lakes Research 23:416-439.

Savino, J. F., M. A. Blouin, B. M. Davis, P. L. Hudson, T. N. Todd, and G. W. Fleischer. 1994. Effects of pulsed turbidity and vessel traffic on lake herring eggs and larvae. Journal of Great Lakes Research 20:366-376.

Schreiner, D. R., and S. T. Schram. 2001. Lake Superior fish aging manual. Great Lakes Fishery Commission, Ann Arbor, Michigan.

Smith, S. H. 1970. Species interactions of the alewife in the Great Lakes. Transactions of the American Fisheries Society 99:754-765.

Sokal, R. R., and F. J. Rohlf. 1969. Biometry. Freeman, San Francisco.

Stockwell, J. D., M. P. Ebener, J. A. Black, O. T. Gorman, T. R. Hrabik, R. E. Kinnunen, W. P. Mattes, J. K. Oyadomari, S. T. Schram, D. R. Schreiner, M. J. Seider, S. P. Sitar, and D. L. Yule. 2009. A synthesis of cisco recovery in Lake Superior: implications for native fish rehabilitation in the Laurentian Great Lakes. North American Journal of Fisheries Management 29:626652.

Wahl, B., and H. Löffler. 2009. Influences on the natural reproduction of whitefish (Coregonus lavaretus) in Lake Constance. Canadian Journal of Fisheries and Aquatic Sciences 66:547-556.

Wells, L., and A. L. McLain. 1973. Lake Michigan: man's effects on native fish stocks and other biota. Great Lakes Fishery Commission Technical Report 20.

Zimmerman, M. S., and C. C. Krueger. 2009. An ecosystem perspective on re-establishing native deepwater fishes in the Laurentian Great Lakes. North American Journal of Fisheries Management 29:1352-1372. 